\title{
Bu-Fei decoction and modified Bu-Fei decoction inhibit the growth of non-small cell lung cancer, possibly via inhibition of apurinic/apyrimidinic endonuclease 1
}

\author{
SHAN-TONG JIANG, SHU-YAN HAN, LI-NA PANG, YAN-NA JIAO, XI-RAN HE and PING-PING LI
}

Key Laboratory of Carcinogenesis and Translational Research (Ministry of Education/Beijing), Department of Integration of Chinese and Western Medicine, Peking University Cancer Hospital \& Institute, Beijing 100142, P.R. China

Received December 7, 2016; Accepted January 15, 2018

DOI: $10.3892 / \mathrm{ijmm} .2018 .3444$

\begin{abstract}
Human apurinic/apyrimidinic endonuclease 1 (APE1) is a ubiquitous multifunctional protein, which possesses DNA repair and redox activities. High levels of APE1 are associated with chemo- and radioresistance, and poor prognosis in various types of cancer, including non-small cell lung cancer (NSCLC). Bu-Fei decoction (BFD) is a traditional Chinese herbal formula, which is believed to supplement Qi, clear away heat and nourish the lungs. BFD and modified Bu-Fei decoction (MBFD) have been used in China to treat patients with lung cancer. The present study aimed to evaluate the potential antitumor effects of BFD and MBFD on NSCLC in vitro and in vivo. In addition, the possible contribution of APE1 was examined. MTT assay was used to investigated the anti-tumor activity of BFD and MBFD on H1975 and H292 NSCLC cell lines. The DNA damage of cells in the control and the experimental groups was detected using comet assay. The in vivo anti-tumor effects of BFD and MBFD were evaluated in a NSCLC tumor nude mouse xenograft model. Polymerase chain reaction (PCR), reverse transcription-quantitative PCR (RT-qPCR) analysis and western blot analysis were applied to analyze the mRNA and protein expression levels of APE1 in H1975 and H292 cells, so as to the xenograft tumor tissues. The concentration of APE1 in mice plasma was determined
\end{abstract}

Correspondence to: Professor Ping-Ping Li, Key Laboratory of Carcinogenesis and Translational Research (Ministry of Education/Beijing), Department of Integration of Chinese and Western Medicine, Peking University Cancer Hospital \& Institute, 52 Fu-Cheng Road, Beijing 100142, P.R. China

E-mail: jiangshantong@sina.com

Abbreviations: NSCLC, non-small cell lung cancer; BFD, Bu-Fei decoction; APE1, apurinic/apyrimidinic endonuclease 1; MBFD, modified Bu-Fei decoction

Key words: non-small cell lung cancer, apurinic/apyrimidinic endonuclease 1, traditional Chinese medicine, Bu-Fei decoction, modified Bu-Fei decoction using enzyme linked immunosorbent assay (ELISA). In vitro, BFD and MBFD inhibited the growth of cultured H1975 and H292 NSCLC cells. The results of a comet assay revealed that BFD and MBFD increased DNA damage. Furthermore, the expression levels of APE1 were decreased in response to BFD and MBFD at the mRNA and protein levels. In mice carrying NSCLC xenografts, BFD and MBFD inhibited tumor growth and decreased APE1 expression. In addition, in normal human lung bronchial epithelial BEAS-2B cells, the half maximal inhibitory concentrations of BFD and MBFD were much higher compared with in NSCLC cells, and they had no effect on DNA damage. These results suggested that BFD and MBFD may inhibit the growth of NSCLC, possibly by inhibiting APE1 expression.

\section{Introduction}

DNA damage is an important etiological factor in lung cancer (1), and various types of DNA damage exist, including nucleotide alterations (deletions, insertions and substitutions of nucleotides), single-strand breaks and double-strand breaks (2). When DNA damage occurs, a set of DNA repair pathways are activated (3-5). Among these pathways, the base excision repair (BER) pathway is responsible for repairing the majority of DNA damage caused by alkylation and oxidative stress $(4,6)$.

Human apurinic/apyrimidinic (AP) endonuclease 1 (APE1), also known as APE, APEX and Ref-1, is a ubiquitous multifunctional protein, which is associated with BER and redox activities. APE1 is a rate-limiting enzyme in the BER pathway (7-9). When base damage occurs, glycosylases in the cell excise the damaged base to generate an AP, or abasic, site. Unlike other glycosylases, APE1 is the only enzyme that can process the BER abasic site; APE1 hydrolyzes the phosphodiester backbone $5^{\prime}$ to the AP site, creating a normal 3 ' hydroxyl terminus and an abasic 5' deoxyribose phosphate terminus. During this process, APE1 also recruits various polymerases and ligases to participate in the repair. Mammalian APE1 also affects numerous DNA transcription factors, including hypoxia inducible factor (HIF)-1 $\alpha$, activator protein (AP)-1, nuclear factor (NF) $-\kappa B$ and p53 (10), and by doing so, indirectly contributes to DNA repair. 
APE1 is the only DNA repair protein known to have redox regulatory activity $(8,10)$, and is responsible for $95 \%$ of cellular endonuclease activity $(7,8)$. APE1 is able to regulate the reducing state of amino acid residues at key sites of transcription factors, and therefore participates in various basic cellular events, including proliferation, differentiation, apoptosis and transformation. The expression levels, aberrant subcellular localization and the patterns of post-translational modification of APE1 have been implicated in chemo- and radioresistance $(11,12)$, and are associated with poor prognosis in numerous types of cancer, including non-small cell lung cancer (NSCLC) (13-22). Serum APE1 autoantibody has been proposed as a potential tumor marker and predictor of responses to chemotherapy in patients with NSCLC (23).

Lung cancer accounts for $13 \%$ of all new cases of malignant tumors and $19.4 \%$ of cases of malignant tumor-associated mortality (24). The latest cancer statistics have revealed increasing morbidity and mortality of lung cancer in developed and developing countries $(25,26)$. Approximately $85 \%$ of all patients with lung cancer have NSCLC. In patients who are not a candidate for surgery, therapeutic approaches mainly include chemotherapy and targeted therapy (27-29). However, despite advances in treatment, the five-year survival rate remains $<17.4 \%$ (30).

Under the theoretical framework of traditional Chinese medicine (TCM), lung cancer is believed to reflect external invasion, which may lead to disharmonious lung functions, and ultimately results in the obstruction of lung Qi and blood stasis. Previous studies regarding TCM and lung cancer (31-36) have suggested that supplementing the center, and boosting Qi and anti-inflammatory function, may prolong patient survival and improve the quality of life (QOL) for patients with NSCLC. The major ingredients of original Bu-Fei decoction (BFD) are Milkvetch root (Huang-Qi), Radix Asteris (Zi-Yuan) and Cortex Mori Radicis (Sang-Bai-Pi). In addition, modified BFD (MBFD) lsocontains Hedyotic diffusa (Bai-Hua-She-She-Cao), Duchesnea (She-Mei) and Scutellaria barbata (Ban-Zhi-Lian). He et al demonstrated that BFD attenuated TGF- $\beta 1$-mediated epithelial-mesenchymal transition in lung cancer A549 cells via decreasing canonical Smad signaling pathway (37). BFD has been shown to exhibit immunomodulatory effects and possess anti-tumor activities (38). The present study aimed to examine the potential antitumor effects of BFD and MBFD on representative NSCLC cell lines and a mouse xenograft model.

\section{Materials and methods}

Cell culture. The H1975 and H292 human lung cancer cell lines, and the BEAS-2B human lung bronchial epithelial cell line, were purchased from American Type Culture Collection (Manassas, VA, USA). The cells were grown in RPMI-1640 medium (Thermo Fisher Scientific, Inc.) containing $10 \%$ fetal bovine serum (FBS; Gibco; Thermo Fisher Scientific, Inc.) and maintained at $37^{\circ} \mathrm{C}$ in an atmosphere containing $5 \% \mathrm{CO}_{2}$.

$B F D$ and $M B F D$. The BFD decoction is composed of 6 medicinal herbs: milkvetch root (Huang-Qi), Radix asteris (Zi-Yuan), Cortex Mori Radicis (Sang-Bai-Pi), Rehmannia glutinosa (Di-Huang), Codonopsis pilosula (Dang-shen) and Schisandra chinensis (Wu-Wei-Zi), Hedyotic diffusa (Bai-Hua-She-She-Cao), Duchesnea (She-Mei) and Scutellaria barbata (Ban-Zhi-Lian) were added to make MBFD. The components of BFD and MBFD were converted into formula granules by Beijing Tcmages Pharmaceuticals Co., Ltd. (Beijing, China) at a receiving rate of 18.8 and $14.1 \%$, respectively. The quality of the BFD and MBFD granules was monitored by Fourier transform infrared spectroscopy (model IRPRestige-21; Shimadzu Corp., Kyoto, Japan). Prior to use, the formula granules were dissolved in deionized water at about $50^{\circ} \mathrm{C}$, centrifuged at $13,800 \mathrm{x}$ g for $30 \mathrm{~min}$ to remove drug sediment, and sterilized by filtration through a $0.22 \mu \mathrm{m}$ membrane (EMD Millipore, Billerica, MA, USA); finally, the solutions were stored at $-80^{\circ} \mathrm{C}$. The concentrations of BFD and MBFD indicated in the subsequent text denote crude drug concentrations.

Cell proliferation assay. Cells were resuspended in RPMI-1640 at a density of $1 \times 10^{4}$ cells/well in 96-well plates (Costar; Corning Incorporated, Corning, NY, USA). Drug exposure was conducted after culturing for $24 \mathrm{~h}$ and were treated with the drugs alongside $1 \%$ FBS in an atmosphere containing 5\% $\mathrm{CO}_{2}$. $\mathrm{H} 1975, \mathrm{H} 292$ and BEAS-2B cells were treated with BFD $(0-30 \mathrm{mg} / \mathrm{ml})$ or $\operatorname{MBFD}(0-15 \mathrm{mg} / \mathrm{ml})$ for 24 h. $\beta$-actin (\#4790; dilution, 1:10,000; Cell Signaling Technology, Inc., Danvers, MA, USA) was used as a loading control in cell proteins and GAPDH (\#5174; dilution, 1:10,000; Cell Signaling Technology, Inc.) in tissue proteins. Cells were then incubated with MTT at a final concentration of $0.5 \mathrm{mg} / \mathrm{ml}$ (Sigma-Aldrich; Merck KGaA, Darmstadt, Germany) at $37^{\circ} \mathrm{C}$ for $4 \mathrm{~h}$, then MTT was replaced by $150 \mu \mathrm{l}$ dimethyl sulfoxide, incubated for $15 \mathrm{~min}$ at room temperature. Absorbance (optical density) was measured at $570 \mathrm{~nm}$ using a microplate reader (Model 680; Bio-Rad Laboratories, Inc., Hercules, CA, USA).

Flow cytometry and cell cycle analysis. Cells were resuspended in RPMI-1640 at a density of $3 \times 10^{5}$ cells/well in 6 -well plates (Costar; Corning Incorporated). Drug exposure was conducted after culturing for $24 \mathrm{~h}$ and at $1 \%$ FBS. H1975 cells were treated with BFD (0-30 mg/ml) or MBFD $(0-15 \mathrm{mg} / \mathrm{ml})$ for $24 \mathrm{~h}$; H292 cells were treated with BFD $(0-30 \mathrm{mg} / \mathrm{ml})$ or MBFD $(0-20 \mathrm{mg} / \mathrm{ml})$ for $24 \mathrm{~h}$ at $37^{\circ} \mathrm{C}$ in an atmosphere containing $5 \% \mathrm{CO}_{2}$. Cells were then collected, fixed with cold $75 \%$ ethanol and stored at $-20^{\circ} \mathrm{C}$ for $\geq 24 \mathrm{~h}$. Subsequently, after washing twice with cold PBS, cells were incubated with propidium iodide (PI)/RNase staining buffer (BD Biosciences, San Diego, CA, USA) for $15 \mathrm{~min}$ at room temperature. DNA content was analyzed by flow cytometry using BD Accuri C6 (version 1.0.264.15; BD Biosciences). The percentage of cells in the various phases of the cell cycle was determined using ModFit LT 4.1 software (BD Biosciences).

Annexin V/PI staining assay. Annexin V/PI staining was performed using an apoptosis detection kit (Dojindo Molecular Technologies, Inc., Kumamoto, Japan). Following treatment, cells were collected and dissolved in $100 \mu \mathrm{l}$ Annexin $\mathrm{V}$ binding buffer $\left(5 \times 10^{5}\right.$ cells $\left./ \mathrm{ml}\right)$. To $100 \mu \mathrm{l}$ of each sample, $5 \mu \mathrm{l}$ Annexin $\mathrm{V}$ and $5 \mu \mathrm{l}$ PI were added, and the samples were incubated for $15 \mathrm{~min}$ at room temperature. Analysis of apoptosis was performed using BD Accuri C6. Annexin V-negative/PI-negative cells were identified as viable cells, Annexin V-positive/PI-negative cells were recognized 
as early apoptotic cells, and Annexin V-positive/PI-positive cells were identified as late apoptotic/dead cells.

Comet assay. Cells were suspended in ice-cold $1 \mathrm{X}$ PBS $\left(\mathrm{Ca}^{2+}\right.$ and $\mathrm{Mg}^{2+}$-free) to a concentration of $2 \times 10^{5}$ cells $/ \mathrm{ml}$. DNA strand breaks were evaluated using Trevigen CometAssay ${ }^{\circledR}$ kit (Trevigen, Gaithersburg, MD, USA). Cells $\left(2 \times 10^{5}\right.$ cells $\left./ \mathrm{ml}\right)$ were mixed with molten LMAgarose at a volume ratio of 1:10 and the mixture was immediately evenly spread onto comet slides, which were incubated at $4^{\circ} \mathrm{C}$ in the dark for $10 \mathrm{~min}$. The slides were then transferred to prechilled lysis solution for $60 \mathrm{~min}$ at $4^{\circ} \mathrm{C}$.

For the alkaline comet assay, slides were incubated in $300 \mathrm{mM} \mathrm{NaOH}$ containing $1 \mathrm{mM}$ EDTA $(\mathrm{pH}>13)$ for $20 \mathrm{~min}$ at room temperature in the dark, and were electrophoresed at $1 \mathrm{~V} / \mathrm{cm}$ and $300 \mathrm{~mA}$ for $40 \mathrm{~min}$. After extensive rinsing, slides were incubated in $70 \%$ ethanol for $5 \mathrm{~min}$ and dried. Finally, DNA was stained with SYBR-Green I dye (1:10,000

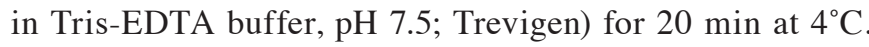
Images were captured using a fluorescence microscope (TCS SP5; Leica Microsystems GmbH, Wetzlar, Germany).

For the neutral comet assay, samples were immersed in $50 \mathrm{ml} 1 \mathrm{X}$ neutral electrophoresis buffer for $30 \mathrm{~min}$ at $4^{\circ} \mathrm{C}$, separated by electrophoresis at $1 \mathrm{~V} / \mathrm{cm}$ for $40 \mathrm{~min}$, and transferred to DNA precipitation solution for $30 \mathrm{~min}$ at room temperature. After drying, DNA was stained with SYBR-Green I dye (1:10,000 in Tris-EDTA buffer, pH 7.5; Trevigen) for $20 \mathrm{~min}$ at $4^{\circ} \mathrm{C}$. Images were captured using a fluorescence microscope (TCS SP5; Leica Microsystems GmbH).

Comet analysis. The percentage of DNA in the tail (the percentage of total cell DNA found in the tail) and tail moment (the amount of DNA in the tail combined with the distance of migration) are common descriptors of DNA damage determined by alkaline comet and neutral comet assays, respectively. At least 50 randomly selected cells were analyzed for each slide using TriTek CometScore ${ }^{\mathrm{TM}}$ Freeware v1.5 image analysis software (TriTek Corporation, Sumerduck, VA, USA).

Small interfering (si)RNA and plasmid transfection. Cells were transfected with APE1 siRNA $\left[\left(5^{\prime} \rightarrow 3^{\prime}\right)\right.$ : GTTGGCGCCTTGATTACTT] or a scrambled RNA control (Guangzhou Ribobio Co., Ltd., Guangzhou, China) at a final concentration of 80 pM using Lipofectamine ${ }^{\circledR} 2000$ (Invitrogen, Carlsbad, CA, USA). pReceiver-M98 plasmid containing the APE1 gene (cat. no. EX-C0496-M98-5) and an empty plasmid were synthesized by GeneCopoeia (Rockville, MD, USA). Transfection efficiency was confirmed by western blot analysis. Cells were re-suspended in RPMI-1640 at a density of $2 \times 10^{5}$ cells/well in 24-well plates (Costar; Corning Incorporated), cultured for $24 \mathrm{~h}$ at $37^{\circ} \mathrm{C}$ in an atmosphere of $5 \% \mathrm{CO}_{2}$. Before transfection, dilution of $0.8 \mu \mathrm{g}$ DNA in $50 \mu \mathrm{l}$ Opti-MEM medium without serum (Gibco, Grandsland, NY, USA) and dilution of $2 \mu 1$ Lipofectamine ${ }^{\circledR} 2000$ in $50 \mu 1$ Opti-MEM Medium without serum was made, and incubation for $5 \mathrm{~min}$ at room temperature followed. The diluted DNA and diluted Lipofectamine ${ }^{\circledR} 2000$ (total volume $=100 \mu \mathrm{l}$ ) were combined and incubation for $20 \mathrm{~min}$ at room temperature followed. A total of $100 \mu \mathrm{l}$ of complexes was then added to each well containing cells and $400 \mu \mathrm{l}$ RPMI-1640 medium; cells were incubated at $37^{\circ} \mathrm{C}$ in an atmosphere of $5 \% \mathrm{CO}_{2}$ for $24 \mathrm{~h}$. Same as the plasmid transfection, $40 \mathrm{pmol}$ siRNA and $1 \mu 1$ Lipofectamine ${ }^{\circledR} 2000$ were used in the siRNA transfection protocol. Transfection was conducted $48 \mathrm{~h}$ prior to drug treatment with BFD or MBFD.

$R N A$ isolation, polymerase chain reaction $(P C R)$ and reverse transcription-quantitative PCR (RT-qPCR) analysis. Total RNA was extracted from cells using TRIzol ${ }^{\circledR}$ reagent (Invitrogen; Thermo Fisher Scientific, Inc.). RT was performed using the TransScript First-Strand cDNA synthesis supermix (Beijing Transgen Biotech Co., Ltd., Beijing, China) according to the manufacturer's protocol. The concentration and quality of extracted RNA were verified using a NanoDrop 2000 (NanoDrop; Thermo Fisher Scientific, Inc., Wilmington, DE, USA). RT was performed using the TransScript First-Strand cDNA synthesis supermix (Beijing Transgen Biotech Co., Ltd., Beijing, China). PCR was conducted according to the standard protocol of EasyTag supermix (Beijing Transgen Biotech Co., Ltd.) and DNA amplification was performed using a PCR thermocycler (S1000TM, Thermal Cycler; Bio-Rad Laboratories, Inc.). The cycling conditions were as follows: One cycle at $95^{\circ} \mathrm{C}$ for $5 \mathrm{~min}$, followed by 30 cycles at $95^{\circ} \mathrm{C}$ for $30 \mathrm{sec}, 60^{\circ} \mathrm{C}$ for $30 \mathrm{sec}$ and $72^{\circ} \mathrm{C}$ for $35 \mathrm{sec}$. The amplification products were separated by $1 \%$ agarose gel electrophoresis and were analyzed using an ultraviolet transilluminator (GelDoc ${ }^{\mathrm{TM}}$ EZ; Bio-Rad Laboratories, Inc.). RT-qPCR was performed using a SYBR-Green qPCR Supermix (Applied Biosystems; Thermo Fisher Scientific, Inc.) on an ABI Prism 7500 sequence detection system (Applied Biosystems; Thermo Fisher Scientific, Inc.). The cycling conditions were as follows: One cycle at $35^{\circ} \mathrm{C}$ for $10 \mathrm{~min}$, followed by 40 cycles at $95^{\circ} \mathrm{C}$ for $30 \mathrm{sec}, 60^{\circ} \mathrm{C}$ for $30 \mathrm{sec}$ and $72^{\circ} \mathrm{C}$ for $35 \mathrm{sec}$. The specific primers designed for PCR were synthesized by Sangon Biotech Co., Ltd. (Shanghai, China); the sequences were as follows $\left(5^{\prime} \rightarrow 3^{\prime}\right)$ : APE1, forward GAGTAAGA CGGCCGCAAAGAAAAA, reverse CCGAAGGAGCT GACCAGTATTGAT; and GAPDH, forward GGTGAAGG TCGGTGTGAACG and reverse CTCGCTCCTGGAA GATGGTG. Cells were resuspended in RPMI-1640 at a density of $3 \times 10^{5}$ cells/well in 6-well plates (Costar; Corning Incorporated). Drug exposure was conducted after culture for $24 \mathrm{~h}$ and at $1 \%$ FBS. H1975 cells were treated with BFD $(0-30 \mathrm{mg} / \mathrm{ml})$ or MBFD $(0-15 \mathrm{mg} / \mathrm{ml})$ for $24 \mathrm{~h}$; H292 cells were treated with BFD $(0-30 \mathrm{mg} / \mathrm{ml})$ or MBFD $(0-20 \mathrm{mg} / \mathrm{ml})$ for $24 \mathrm{~h}$. Following treatment, the cells were washed with ice-cold PBS and lysed with RIPA buffer (CWBIO, Beijing, China). Protein concentration was detected using a BCA protein assay kit (Thermo Fisher Scientific, Inc.). The specificity of amplification was confirmed via melting curve analysis. The mRNA expression levels of APE1 relative to GAPDH were calculated using the $\triangle \Delta \mathrm{Cq}$ method, as described previously (39).

Western blot analysis. Samples (15 $\mu \mathrm{g}$ protein) were separated by $12 \%$ SDS-PAGE and were transferred to polyvinylidene difluoride membranes (EMD Millipore). The membranes were then blocked with 5\% skim milk for $1 \mathrm{~h}$ at room temperature, and were incubated with APE1 antibody (ab92744; dilution, 

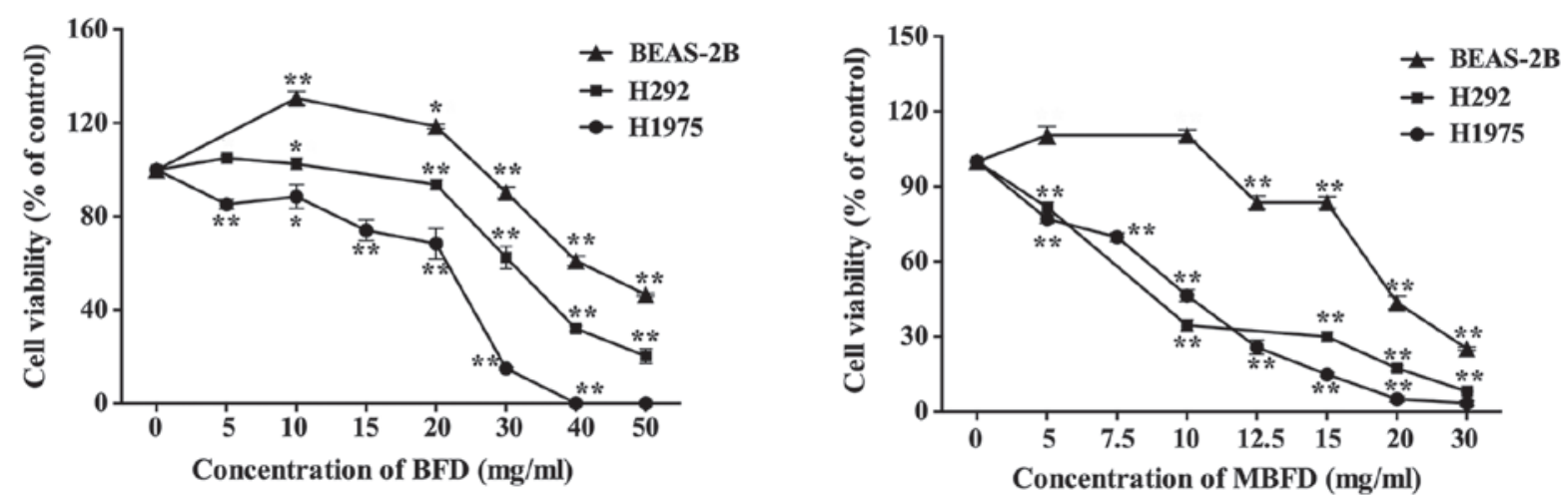

Figure 1. Effects of BFD and MBFD on the proliferation of lung cancer cell lines and human lung bronchial epithelial cells. "P<0.05 and ${ }^{* *} \mathrm{P}<0.001$ vs. the control group. BFD, Bu-Fei decoction; MBFD, modified BFD.

1:20,000; Abcam, Cambridge, MA, USA) overnight at $4^{\circ} \mathrm{C}$. The membranes were washed with Tris-buffered saline containing $0.05 \%$ Tween and were then incubated with horseradish peroxidase-conjugated secondary antibody (cat. no. 129736; dilution, 1:10,000; ZSGB-BIO Co., Ltd, Beijing, China) for $1 \mathrm{~h}$ at room temperature. Finally the blots were visualized using chemiluminescence (EMD Millipore). $\beta$-actin (\#4790; dilution, 1:10,000; Cell Signaling Technology, Inc.) was used as a loading control. Semi-quantitative analysis of the blots was performed using ImageJ2x (National Institutes of Health, Bethesda, MD, USA). Protein concentration was determined using the bicinchoninic acid method prior to western blotting.

Nude mouse xenograft model. Female BALB/c nude mice (n=50; age, 6-8 weeks; weight, $22 \mathrm{~g}$; National Institutes for Food and Drug Control, Beijing, China) were housed in environmentally controlled cabinets (temperature, $23 \pm 2^{\circ} \mathrm{C} ; 12$-h light/dark cycle; relative humidity, $50 \%$; normal food and water) under specific pathogen-free conditions for 7 days prior to experimentation. Protocols were performed in accordance with the US Animal Welfare guidelines (40), and the present study was approved by the Institutional Animal Care and Use Committee of the First Hospital Affiliated to PLA General

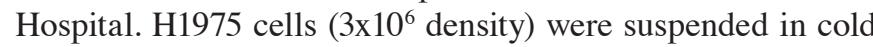
PBS mixed with Matrigel (BD Biosciences) at a volume ratio of 1:1, and were subcutaneously inoculated into the right flank of nude mice.

The weight of tumor-bearing mice was measured and tumor volume was calculated according to the following formula: Tumor volume $\left(\mathrm{mm}^{3}\right)=\left(\right.$ length $\mathrm{x}$ width $\left.{ }^{2}\right) / 2$. The daily dosage for nude mice experiments (BFD and MBFD at 15.17 and $24.42 \mathrm{~g} / \mathrm{kg}$, respectively) was based on human use (1.23 and $1.98 \mathrm{~g} / \mathrm{kg}$, respectively), as described previously (41). When tumor volume reached $50-100 \mathrm{~mm}^{3}$, mice were randomly divided into five groups (n=10/group): Control, BFD (30 g/ $/ \mathrm{kg}$ ), $\operatorname{BFD}(60 \mathrm{~g} / \mathrm{kg}), \operatorname{MBFD}(48 \mathrm{~g} / \mathrm{kg})$ and MBFD $(96 \mathrm{~g} / \mathrm{kg})$. Drugs were orally administered twice daily for 21 consecutive days. After 21 days, the mice were sacrificed. The blood samples $(0.5 \mathrm{ml})$ were collected from foss orbital veins into heparinized polythene tubes. Tumors were resected and weighed after the mice were sacrificed. Tumor tissues were fixed in formalin and in ice-cold PIPA lysate buffer for protein detection.
ELISA assay. The protein concentration of APE1 was determined in mouse plasma samples using a commercial ELISA kit (Beijing Keyingmei Technology, Beijing, China). The blood samples $(0.5 \mathrm{ml})$ were collected from foss orbital veins into heparinized polythene tubes. After placement at $4^{\circ} \mathrm{C}$ for $2 \mathrm{~h}$, and centrifugation at $2,500 \mathrm{rpm}$ for $15 \mathrm{~min}$, the supernatant was collected to a new tube for ELISA.

Statistical analysis. Data are presented as the means \pm standard error of mean of at least three independent experiments. Half maximal inhibitory concentration $\left(\mathrm{IC}_{50}\right)$ was calculated using GraphPad Prism 5.0.1 software (GraphPad Software, Inc., La Jolla, CA, USA). The analysis of variance (ANOVA) was used to compare gene expression levels between the different groups; other comparisons between two groups were analyzed using Student's t-test. All data analyses were conducted using SPSS statistical software 19.0 (IBM Corp., Armonk, NY, USA). $\mathrm{P}<0.05$ was considered to indicate a statistically significant difference.

\section{Results}

Effects of BFD and MBFD on cell proliferation. BFD and MBFD inhibited the proliferation of H1975 and H292 cells in a dose-dependent manner (Fig. 1). The $\mathrm{IC}_{50}$ values of $\mathrm{BFD}$ were $21.66 \pm 1.01,36.84 \pm 0.56$ and $46.02 \pm 0.89 \mathrm{mg} / \mathrm{ml}$ in $\mathrm{H} 1975$, $\mathrm{H} 292$ and BEAS-2B cells, respectively. The $\mathrm{IC}_{50}$ values of MBFD were $9.12 \pm 0.96,12.66 \pm 0.56$ and $18.1 \pm 1.08 \mathrm{mg} / \mathrm{ml}$ in H1975, H292 and BEAS-2B cells, respectively. These results indicated that BEAS-2B cells are less sensitive to BFD and MBFD compared with the two cancer cell lines $(\mathrm{P}<0.01)$.

Effects of BFD and MBFD on cell cycle progression and cell apoptosis. The results of flow cytometry experiments demonstrated that BFD and MBFD have no effects on cell cycle arrest and apoptosis of H1975 and H292 cells (data not shown).

Effects of BFD and MBFD on DNA repair. Treatment with BFD and MBFD increased DNA migration from the nucleus in a concentration-dependent manner, thus suggesting that DNA repair is suppressed. The migration of DNA from the nucleus formed a 'comet tail' (Fig. 2A and B). Tail DNA increased by 11.14-, 25.04- and 45.93-fold, and 1.85-, 4.25- and 
A

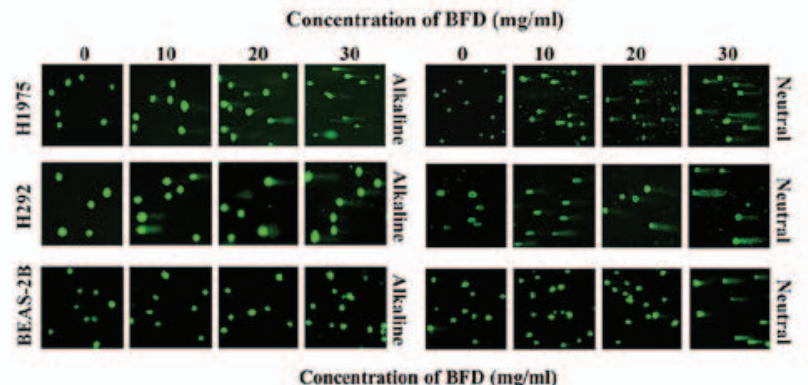

C

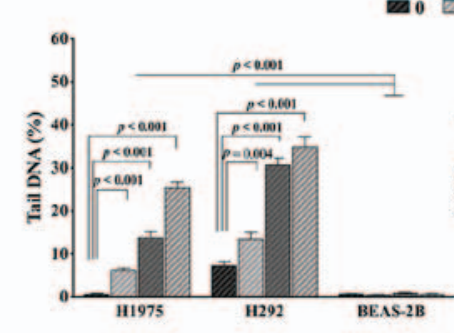

$010 \square 20 \square 30$

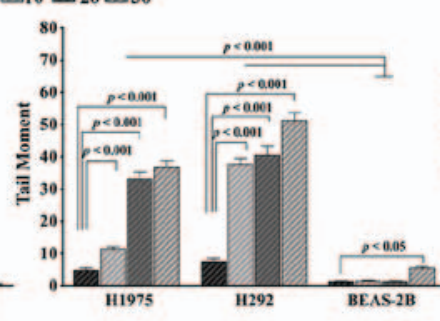

B

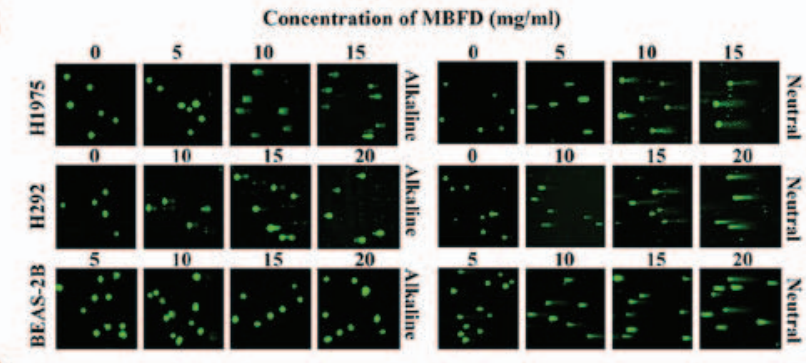

D

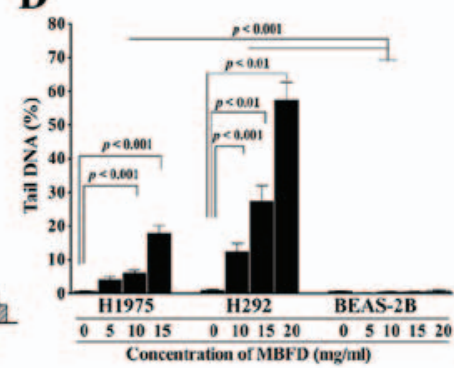

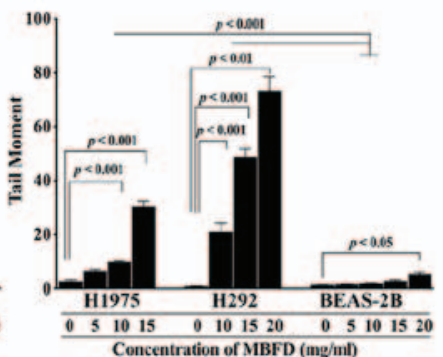

Figure 2. Effects of BFD and MBFD on DNA damage in H1975, H292 and BEAS-2B cells. (A and B) Neutral and alkaline comet assays of H1975 and H292 lung cancer cell lines, and BEAS-2B human lung bronchial epithelial cells, following treatment with BFD and MBFD. Fluorescence microscopy images of samples stained with SYBR-Green I. Original magnification, x100. (C and D) Bar graphs presenting tail moment and tail DNA (\%) in H1975, H292 and BEAS-2B cells following treatment with BFD and MBFD. BFD, Bu-Fei decoction; MBFD, modified BFD.

4.85-fold in H1975 and H292 cells, respectively, by BFD at 10, 20 and $30 \mathrm{mg} / \mathrm{ml}(\mathrm{P}<0.001$ vs. control) (Fig. 2C). BFD did not affect tail DNA in BEAS-2B cells at this concentration range. Tail moment increased by 2.38-, 6.86- and 7.62-fold, and 4.98-, 5.36- and 6.79-fold in H1975 and H292 cells, respectively, by BFD at 10, 20 and $30 \mathrm{mg} / \mathrm{ml}(\mathrm{P}<0.001)$. In BEAS-2B cells, BFD increased tail moment only when used at the highest concentration $(30 \mathrm{mg} / \mathrm{ml})$.

MBFD also increased the extent of DNA damage in H1975 and H292 cells. Tail DNA was increased by 6.37-, 9.72- and 28.21-fold in $\mathrm{H} 1975$ cells in response to 5, 10 and $15 \mathrm{mg} / \mathrm{ml} \mathrm{MBFD}$, respectively $(\mathrm{P}<0.001)$ (Fig. 2D). In H292 cells, tail DNA was increased by 13.77-, 30.56- and 64.07-fold in response to $10(\mathrm{P}<0.001), 15(\mathrm{P}<0.01)$ and $20 \mathrm{mg} / \mathrm{ml}(\mathrm{P}<0.01) \mathrm{MBFD}$, respectively $(\mathrm{P}<0.001)$. BEAS-2B cells were not affected by MBFD. In H1975 cells, tail moment was increased by 2.44-, 3.69- and 11.5 -fold in response to 5, 10 and $15 \mathrm{mg} / \mathrm{ml} \mathrm{MBFD,} \mathrm{respectively.} \mathrm{In} \mathrm{H292} \mathrm{cells,} \mathrm{tail}$ moment was increased by 28.14-, 64.89- and 97.68-fold in response to 10,15 and $20 \mathrm{mg} / \mathrm{ml}$ MBFD, respectively. In BEAS-2B cells, tail moment was increased only when cells were treated with the highest concentration of MBFD.

Effects of APE1 manipulation. Knockdown of APE1 induced DNA damage and inhibited proliferation of the two cancer cell lines (Fig. 3B, and C). Conversely, overexpression of APE1 with a pReceiver-M98 plasmid increased cell proliferation (Fig. 3D). Compared with in the transfection group, treatment with BFD at 10, 20 and $30 \mathrm{mg} / \mathrm{ml}$ concentration inhibited $\mathrm{H} 1975$ cell proliferation by $27.96(\mathrm{P}<0.01), 41.54(\mathrm{P}<0.01)$ and $73.4 \%(\mathrm{P}<0.001)$, respectively, and inhibited $\mathrm{H} 292$ cell proliferation by 13.6 $(\mathrm{P}<0.05), 25.2(\mathrm{P}<0.01)$ and 46.16\% $(\mathrm{P}<0.001)$, respectively. In addition, treatment with MBFD at 5, 10 and $15 \mathrm{mg} / \mathrm{ml}$ concentrations inhibited H1975 cell proliferation by $29.01(\mathrm{P}<0.01), 47.21$ $(\mathrm{P}<0.01)$ and $66.68 \%(\mathrm{P}<0.001)$, respectively, and MBFD at 10 ,
15 and $20 \mathrm{mg} / \mathrm{ml}$ concentrations inhibited H292 cell proliferation by $24.06(\mathrm{P}<0.05), 48.76(\mathrm{P}<0.01)$ and 66.49\% $(\mathrm{P}<0.001)$, respectively.

BFD and MBFD inhibit APE1 mRNA expression in H1975 and H292 cells. The mRNA expression levels of APE1 (296 bp) and GAPDH (353 bp) were subsequently detected (Fig. 4A). Compared with in the control H1975 and H292 cells (untreated cells), the mRNA expression levels of APE1 were decreased following treatment with BFD and MBFD $(\mathrm{P}<0.05)$ (Fig. 4B); however, $10 \mathrm{mg} / \mathrm{ml}$ BFD slightly enhanced APE1 mRNA expression in $\mathrm{H} 1975$ cells $(\mathrm{P}>0.05)$.

BFD and MBFD inhibit APE1 protein expression in H1975 and H292 cell lines. As presented in Fig. 5, treatment with BFD or MBFD decreased APE1 protein expression in H1975 and H292 cells. In H1975 cells, APE1 protein expression levels were reduced by $11.53,24.65(\mathrm{P}<0.01)$ and $34.74 \%(\mathrm{P}<0.001)$ in response to treatment with BFD at 10,20 and $30 \mathrm{mg} / \mathrm{ml}$, respectively; and by $18.42(\mathrm{P}<0.01), 53.51(\mathrm{P}<0.001)$ and $62.17 \%$ $(\mathrm{P}<0.001)$ in response to treatment with MBFD at 5, 10 and $15 \mathrm{mg} / \mathrm{ml}$, respectively. In H292 cells, APE1 protein expression levels were reduced by $8.74,20.57(\mathrm{P}<0.05)$ and $36.84 \%$ $(\mathrm{P}<0.01)$ in response to treatment with BFD at 10, 20, and $30 \mathrm{mg} / \mathrm{ml}$, respectively; and by $24.58,39.79(\mathrm{P}<0.001)$ and $54.61 \%(\mathrm{P}<0.001)$ in response to treatment with MBFD at 10 , 15 and $20 \mathrm{mg} / \mathrm{ml}$, respectively. A closer inspection of the data suggested that MBFD exhibited a stronger effect compared with BFD; the effects of MBFD on APE1 protein expression were more apparent than BFD.

$B F D$ and MBFD suppress tumor growth in nude mice. BFD and MBFD inhibited tumor growth in a mouse xenograft model (Fig. 6A). The tumor growth inhibition rate was $31.97 \%$ following treatment with BFD (30 g/ kg), 36.60\% following 


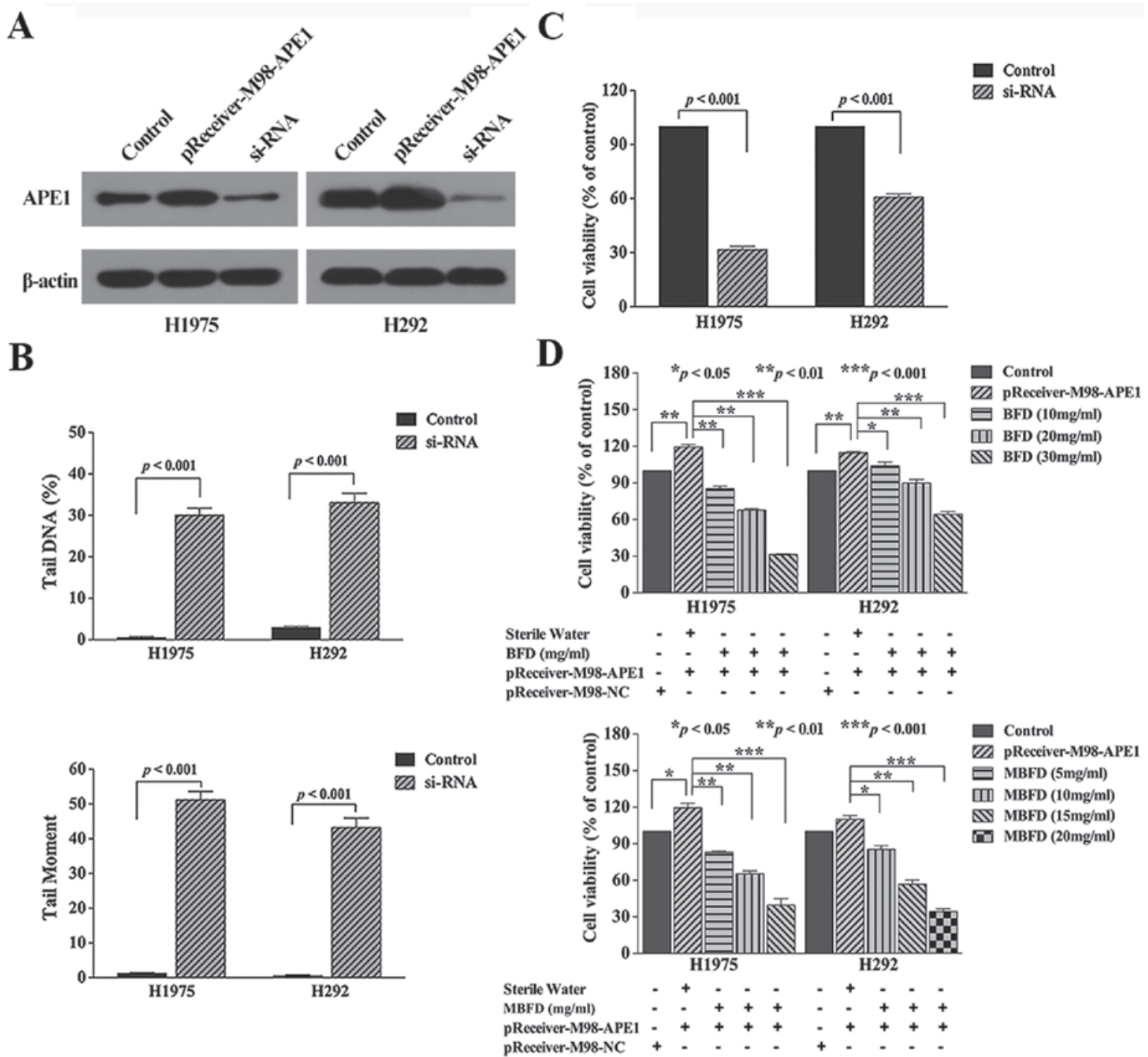

Figure 3. Effects of APE1 on DNA damage and cell proliferation. (A) Verification of transfection efficiency. The control groups were transfected with nothing. (B) Effects of APE1 knockdown on the proliferation of H1975 and H292 cells. (C) Bar graphs presenting tail moment and tail DNA (\%) in H1975 and H292 cells transfected with APE1 siRNA. (B and C) The control groups were transfected with a scrambled RNA control. (D) Effects of APE1 on cell proliferation, and the effects of BFD and MBFD on the proliferation of H1975 and H292 cells overexpressing APE1. APE1, apurinic/apyrimidinic endonuclease 1; BFD, Bu-Fei decoction; MBFD, modified BFD; NC, negative control; siRNA, small interfering RNA.

A
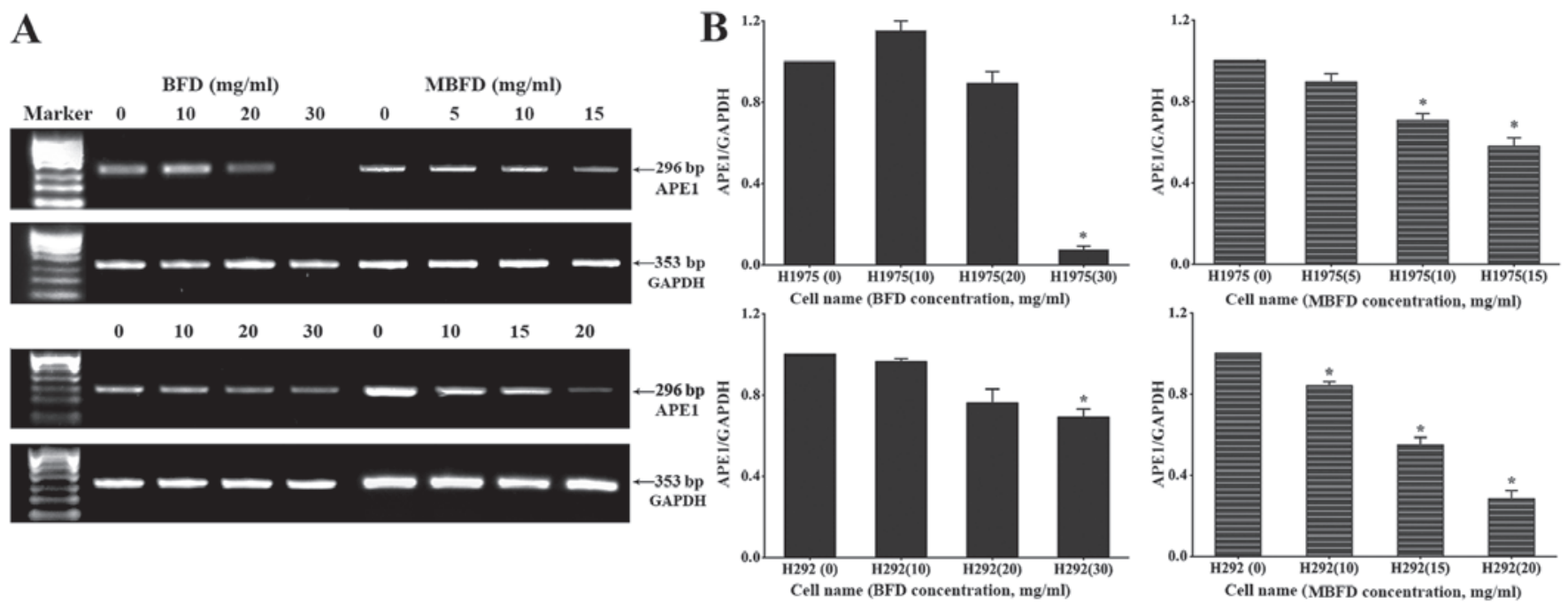

Figure 4. BFD and MBFD inhibit APE1 mRNA expression in H1975 and H292 cells. (A) PCR and (B) quantitative PCR analysis of the mRNA expression levels of APE1. "P<0.05 vs. the control group. APE1, apurinic/apyrimidinic endonuclease 1; BFD, Bu-Fei decoction; MBFD, modified BFD; PCR, polymerase chain reaction. 
A
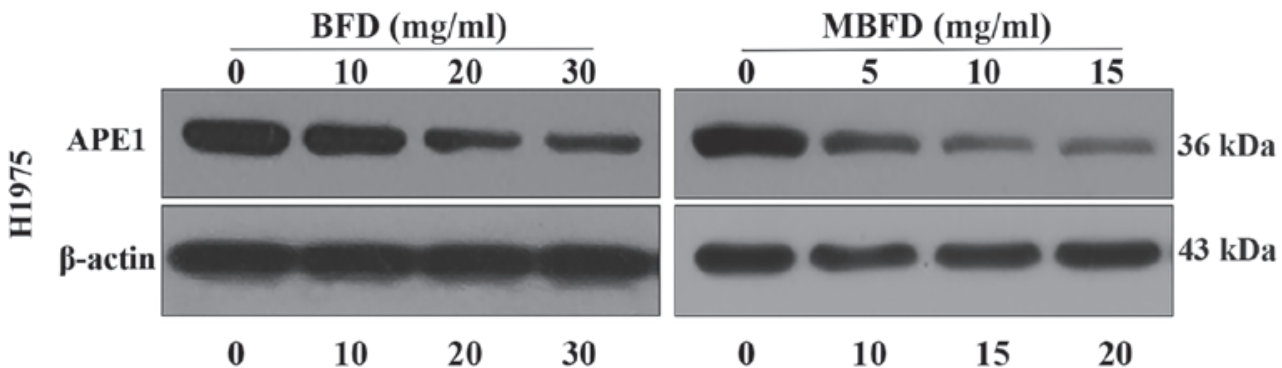

B
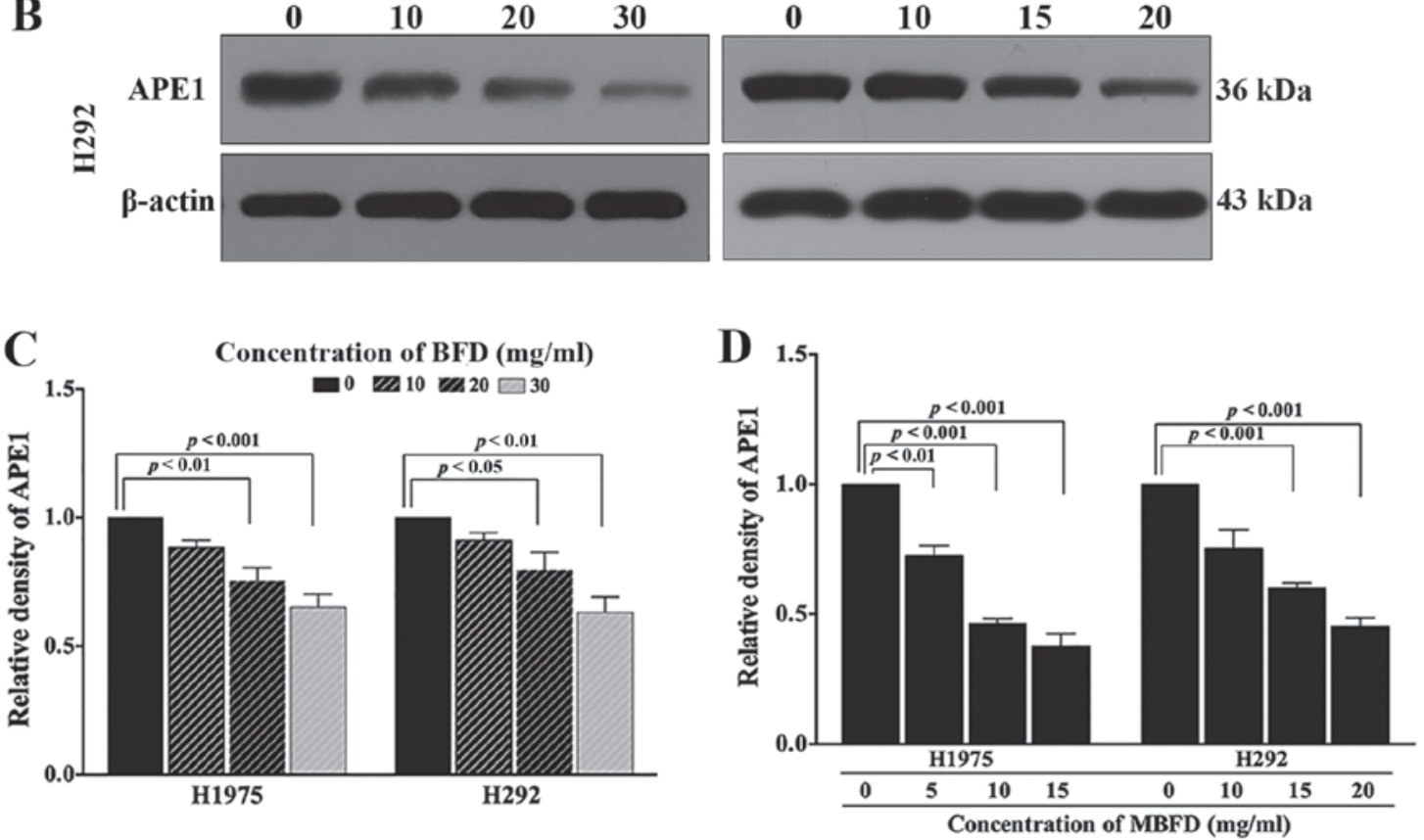

Figure 5. BFD and MBFD inhibit APE1 protein expression in H1975 and H292 cells. (A and B) Western blot analysis of APE1 protein expression in H1975 and H292 cell lines. (C and D) Bar graphs presenting the relative expression of APE1 in H1975 and H292 cells following treatment with BFD and MBFD. APE1, apurinic/apyrimidinic endonuclease 1; BFD, Bu-Fei decoction; MBFD, modified BFD.

treatment with BFD $(60 \mathrm{~g} / \mathrm{kg}), 37.57 \%$ following treatment with MBFD (48 g/ $\mathrm{kg}$ ) and $52.92 \%$ following treatment with MBFD (96 g/kg) (Fig. 6B). There were no significant differences in body weight among the treatment groups at the end of the experiment (Fig. 6C). The alterations in tumor weight were consistent with those in tumor volume (Fig. 6D).

APE1 protein levels are reduced by BFD and MBFD in mouse xenograft tumors. As shown in Fig. 7A and B, APE1 protein expression was reduced by $16.43(\mathrm{P}<0.05), 33.40(\mathrm{P}<0.001)$ and $37.1 \%(\mathrm{P}<0.001)$ in response to treatment with $\mathrm{BFD}$ at $60 \mathrm{~g} / \mathrm{kg}$, $\mathrm{MBFD}$ at $48 \mathrm{~g} / \mathrm{kg}$ and MBFD at $96 \mathrm{~g} / \mathrm{kg}$, respectively. At $30 \mathrm{~g} / \mathrm{kg}$, $\mathrm{BFD}$ did not affect APE1 protein expression $(\mathrm{P}>0.05)$.

$B F D$ and MBFD decrease plasma APE1 concentration. BFD and MBFD significantly decreased plasma APE1 concentrations (Fig. 7C).

\section{Discussion}

According to TCM, BFD supplements Qi, clears away heat and nourishes the lungs, and is believed to treat symptoms caused by insufficiency of Lung-Qi and endogenous heat-induced lung injury. Previous studies regarding the application of BFD in lung cancer have indicated that BFD may be beneficial in reducing lung cancer-associated symptoms and improving the QOL of patients with advanced lung cancer $(42,43)$. Hedyotic diffusa, Duchesnea and Scutellaria barbata are always added in the application of MBFD. A previous study regarding Milkvetch and Codonopsis demonstrated that Milkvetch may induce tumor cell differentiation and death (44). Furthermore, according to TCM, Hedyotic diffusa, Duchesnea and Scutellaria barbata exhibit heat-clearing and detoxifying functions, and Scutellaria barbata possesses antitumor properties. It is also believed that Scutellaria barbata may serve a role strengthening vital Qi to eliminate pathogenic factors; it has been suggested that in advanced cancer a combination of drugs that strengthen vital Qi and antitumor drugs may be beneficial.

Pharmacological studies have reported that Milkvetch, which is the main component of BFD and MBFD, is able to promote the growth of normal cells, improve immunity, accelerate the regeneration of serum and liver proteins, and protect the liver and kidney from damage caused by toxic substances $(45,46)$. In addition, another active ingredient, astragalus polysaccharide, exerts antitumor effects. Epifriedelanol, which is contained in aster flowers, has also been reported to exert an anticancer effect on mouse Ehrlich ascites carcinoma. In addition, Cortex Mori Radicis exerts inhibitory effects on lung cancer cells $(45,46)$. In TCM, it is believed that Hedyotic diffusa possesses strong heat-clearing and detoxifying function $(45,46)$, and it is therefore widely 
A
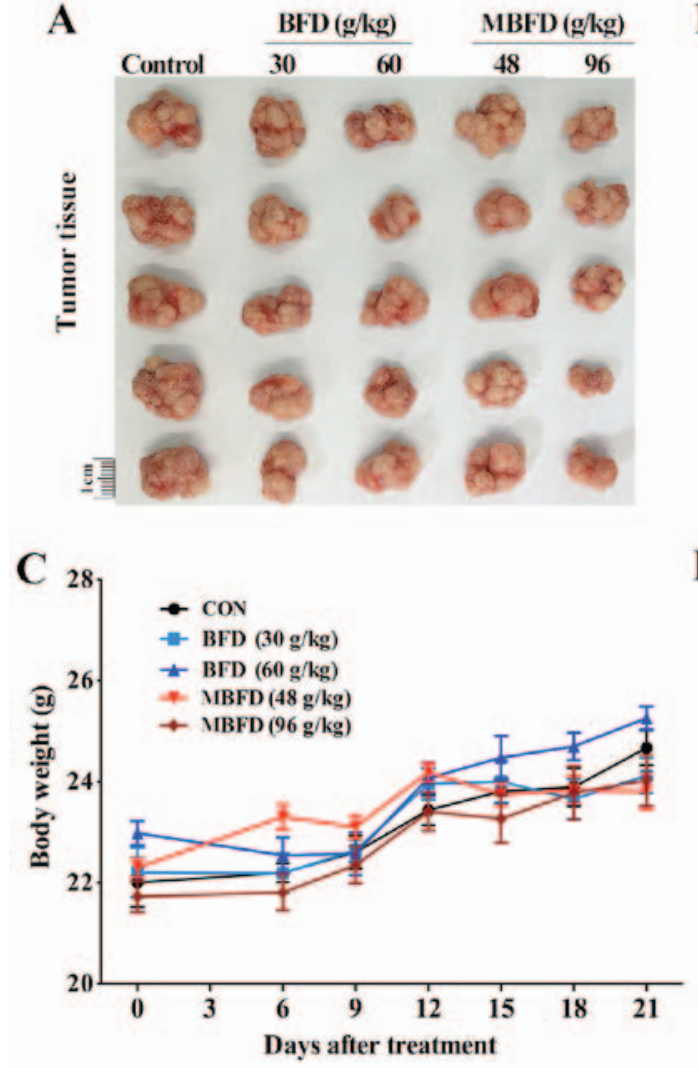

B

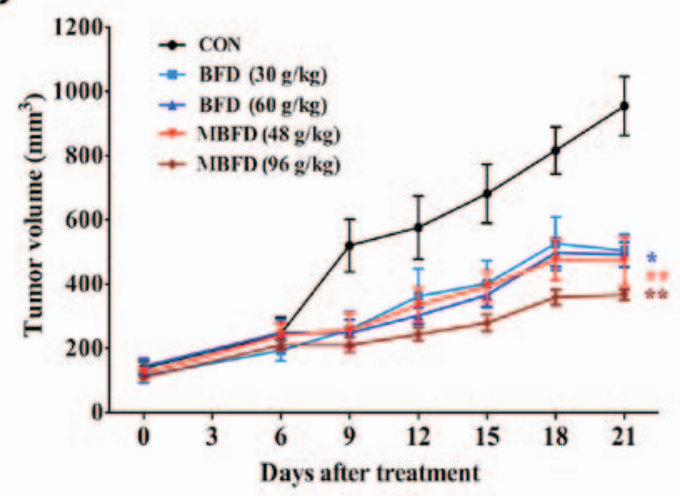

D

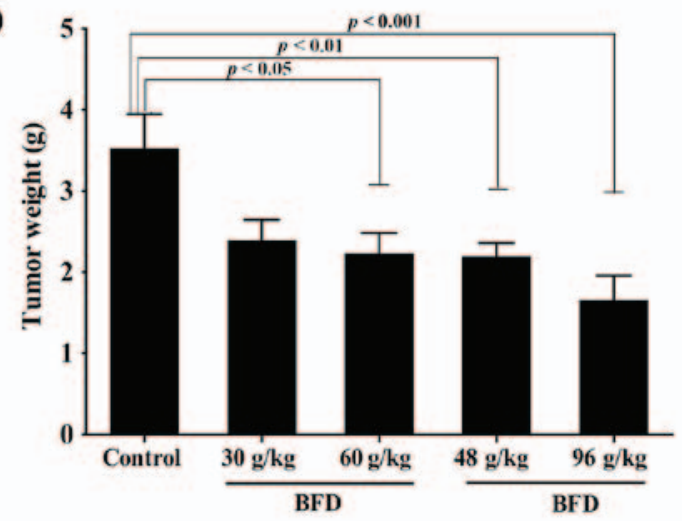

Figure 6. BFD and MBFD suppress tumor growth in a nude mouse xenograft model. (A and B) Tumor volume was calculated, and (C and D) body and tumor weight were assessed. ${ }^{*} \mathrm{P}<0.05,{ }^{* *} \mathrm{P}<0.01$ vs. the control group. BFD, Bu-Fei decoction; MBFD, modified BFD.

used in the treatment of various types of cancer. Experimental studies have indicated that Hedyotic diffusa is able to suppress the proliferation of lung cancer cells, arrest cells in $\mathrm{G}_{0} / \mathrm{G}_{1}$ phase and promote cell apoptosis $(47,48)$. Duchesnea and Scutellaria barbata also exhibit pharmacological effects of detoxification. Previous studies have indicated that the crude extract or active ingredient of these two herbs exert inhibitory effects on the proliferation of lung cancer cell lines and the growth of mouse xenograft tumors; however, they do not exhibit inhibitory effects on normal mammary epithelial cells (49-52). To the best of our knowledge, the present study is the first to provide in vitro and in vivo evidence to support the antitumor effects of BFD and MBFD on NSCLC cells, and their inhibitory effects on APE1 expression.

APE1 is the rate-limiting enzyme in the BER pathway and is the only DNA repair protein with redox regulatory activity, which indirectly affects DNA repair via the modulation of transcription factors (7-10). The present results revealed that the mRNA and protein expression levels of APE1 were decreased in H1975 and H292 lung cancer cells under BFD and MBFD treatment. In addition, BFD and MBFD significantly inhibited the proliferation of H1975 and H292 cells, and the results of comet assays demonstrated that BFD and MBFD suppressed the DNA repair of these two cell lines. Conversely, BFD and MBFD exhibited reduced activity against normal human lung bronchial epithelial BEAS-2B cells, thus indicating that the application of BFD and MBFD is safe for patients with lung cancer. Furthermore, the present in vivo experiments provided strong evidence to support these findings. Consistent with the in vitro results, the administration of BFD and MBFD resulted in suppression of tumor growth and a reduction in the expression of APE1 in mouse plasma samples and tumor tissues compared with in the control group. In addition, no significant differences were detected in body weight between the control and treatment groups. Notably, the appetite and temperament of the mice was better in the treatment groups compared with in the control group. In older to further explore the association between BFD/MBFD and APE1, H292 and H1975 cells were transfected with a siRNA to downregulate the expression of APE1, cells were then treated with BFD and MBFD; the results indicated that DNA damage of H1975 and H292 cells was significantly increased and the proliferation of the two cell lines was significantly reduced in response to APE1 siRNA. In addition, H1975 and H292 cells were transfected with pReceiver-M98 plasmid containing a gene clone of APE1; subsequently, the results of an MTT assay indicated that proliferation of the two cell lines was promoted by APE1 overexpression; however, the effects of cell proliferation were attenuated by BFD or MBFD treatment. It may be hypothesized that BFD and MBFD inhibit proliferation due to an increase in DNA damage via inhibition of APE1 expression.

Notably, MBFD exhibited a better antitumor effect compared with BFD in vivo and in vitro. A possible explanation may be that since MBFD contained more Hedyotic diffusa, Duchesnea and Scutellaria barbata than BFD, the pharmacological activities of these three herbs served a central role in the improved antitumor effects. Clinically, patients with cancer that received Chinese medicine were mostly unable to receive chemotherapy or targeted therapy due to their poor 

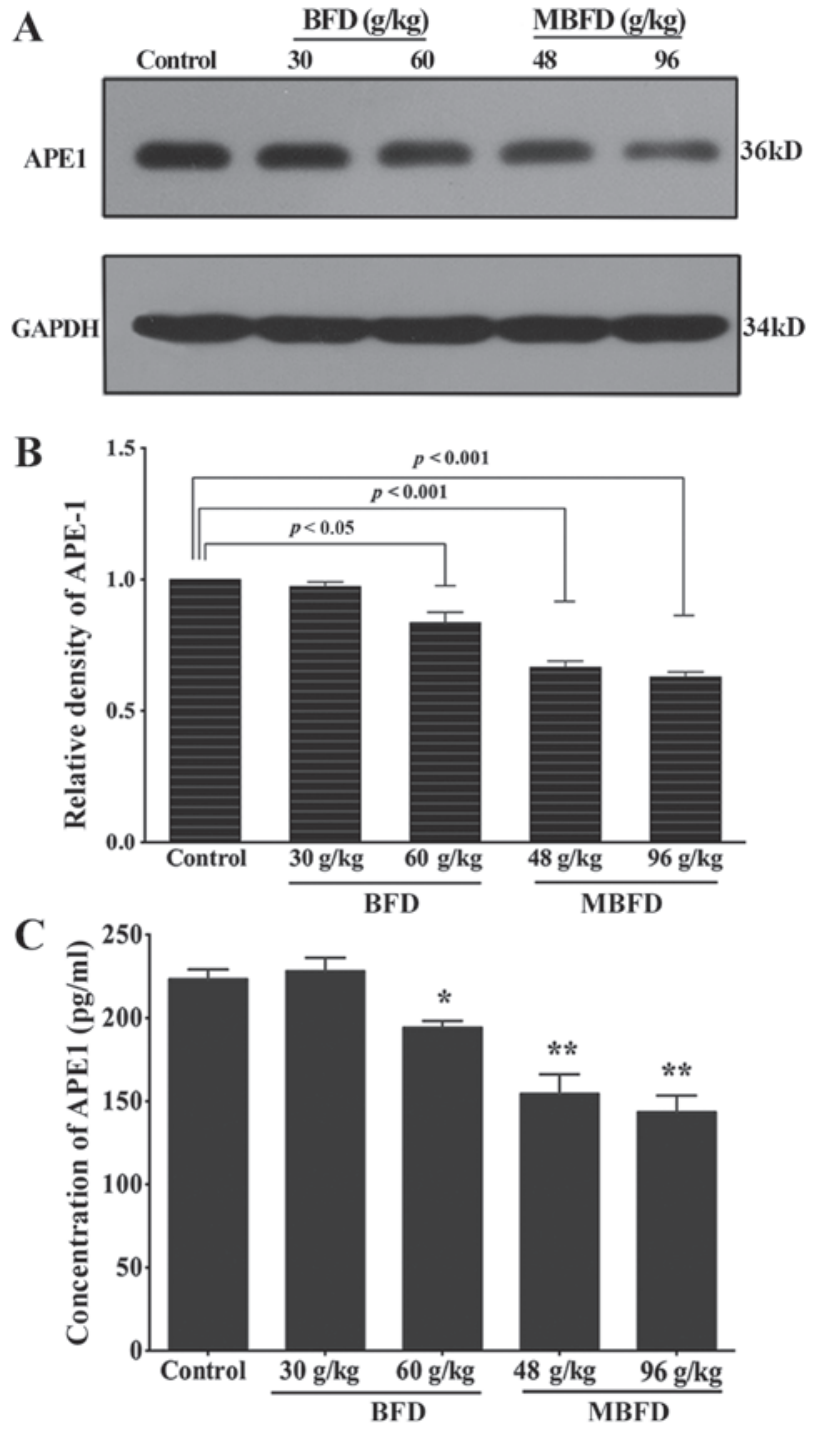

Figure 7. BFD and MBFD inhibit APE1 expression in xenograft tumor tissue and murine plasma samples. (A and B) Western blot analysis of APE1 protein expression in xenograft tumors. (C) BFD and MBFD decreased the concentration of APE1 in murine plasma samples. ${ }^{*} \mathrm{P}<0.05$ and ${ }^{* *} \mathrm{P}<0.001$ vs. the control group. APE1, apurinic/apyrimidinic endonuclease 1; BFD, Bu-Fei decoction; MBFD, modified BFD.

health status. The present study indicated that MBFD strengthened the antitumor effects of BFD, which provides evidence to suggest that MBFD may be applied to treat patients with cancer.

Although the present results revealed the antitumor effects of BFD and MBFD, there are some limitations to the present study. There are various DNA repair pathways, and the results of the comet assays indicated that DNA damage was increased following treatment with BFD or MBFD; however, the reduction in APE1 expression may be just one of the most relevant factors, and targeted evidence is required to verify whether DNA damage was caused by APE1 suppression. Furthermore, as aforementioned, APE1 is a multifunctional protein with DNA repair and redox activities. The current experimental results demonstrated that BFD and MBFD inhibited lung cancer via the suppression of APE1; however, the specific mechanisms by which BFD and MBFD inhibit lung cancer via APE1 require further study. Therefore, future experiments should focus on the effects of BFD/MBFD on the two activities of APE1, including the expression of the associated DNA transcription factors, phosphorylated (p)-NF- $\kappa \mathrm{B}, \mathrm{p}-\mathrm{AP}-1$ and HIF1- $\alpha$, in vivo and in vitro. In addition, the present study observed that, compared with the mice in the control group, the mice in the treatment groups exhibited better appetite and temperament; therefore, it may be hypothesized that BFD and MBFD contribute to improving the QOL of patients with cancer, which is consistent with the characteristics of tonic Chinese herbs, including Milkvetch. Research regarding the underlying mechanism will be conducted in future studies.

In conclusion, the present study demonstrated that BFD and MBFD exert inhibitory effects on NSCLC growth; these antitumor effects may be associated with the inhibition of APE1. These results suggested that BFD and MBFD may be considered promising treatments for NSCLC; in particular, MBFD exhibited a stronger antitumor effect without impacting the body weight and activities of mice. Furthermore, the present study provided evidence to suggest that APE1 may be a target factor for the treatment of NSCLC with TCM.

\section{Acknowledgements}

Not applicable.

\section{Funding}

The present study was partially supported by Beijing Municipal Health System Special Funds of High-level Medical Personnel Construction (grant no. 2014-3-063) and the Key Program Foundation of Beijing Administration of Traditional Chinese Medicines (grant no. 2004-IV15).

\section{Availability of data and materials}

The datasets used and/or analyzed during the current study are available from the corresponding author on reasonable request.

\section{Authors' contributions}

STJ designed and implemented the experiment, and was a major contributor in writing the manuscript. SYH auxiliary designed the experiment. YNJ, LNP and XRH auxiliary implemented the experiment. PPL overall planed and designed the experiment design. All authors read and approved the final manuscript.

\section{Ethics approval and consent to participate}

The present study was approved by the Institutional Animal Care and Use Committee of the First Hospital Affiliated to PLA General Hospital.

\section{Consent for publication}

Not applicable.

\section{Competing interests}

The authors declare that they have no competing interests. 


\section{References}

1. Kastan MB: DNA damage responses: mechanisms and roles in human disease: 2007 G.H.A. Clowes Memorial Award Lecture. Mol Cancer Res 6: 517-524, 2008.

2. Rodriguez-Rocha H, Garcia-Garcia A, Panayiotidis MI and Franco R: DNA damage and autophagy. Mutat Res 711: 158-166, 2011.

3. Altieri F, Grillo C, Maceroni M and Chichiarelli S: DNA damage and repair: from molecular mechanisms to health implications. Antioxid Redox Signal 10: 891-937, 2008.

4. Christmann M, Tomicic MT, Roos WP and Kaina B: Mechanisms of human DNA repair: An update. Toxicology 193: 3-34, 2003

5. Roos WP, Thomas AD and Kaina B: DNA damage and the balance between survival and death in cancer biology. Nat Rev Cancer 16: 20-33, 2016.

6. Wilson DM III and Bohr VA: The mechanics of base excision repair, and its relationship to aging and disease. DNA Repair (Amst) 6: 544-559, 2007.

7. Bhakat KK, Mantha AK and Mitra S: Transcriptional regulatory functions of mammalian AP-endonuclease (APE1/Ref-1), an essential multifunctional protein. Antioxid Redox Signal 11: 621-638, 2009.

8. Li M and Wilson DM III: Human apurinic/apyrimidinic endonuclease 1. Antioxid Redox Signal 20: 678-707, 2014.

9. Wood RD, Mitchell M, Sgouros J and Lindahl T: Human DNA repair genes. Science 291: 1284-1289, 2001.

10. Luo M, He H, Kelley MR and Georgiadis MM: Redox regulation of DNA repair: implications for human health and cancer therapeutic development. Antioxid Redox Signal 12: 1247-1269, 2010

11. Robertson KA, Bullock HA, Xu Y, Tritt R, Zimmerman E, Ulbright TM, Foster RS, Einhorn LH and Kelley MR: Altered expression of Ape1/ref-1 in germ cell tumors and overexpression in NT2 cells confers resistance to bleomycin and radiation. Cancer Res 61: 2220-2225, 2001

12. Wang D, Xiang DB, Yang XQ, Chen LS, Li MX, Zhong ZY and Zhang YS: APE1 overexpression is associated with cisplatin resistance in non-small cell lung cancer and targeted inhibition of APE1 enhances the activity of cisplatin in A549 cells. Lung Cancer 66: 298-304, 2009.

13. Di Maso V, Avellini C, Crocè LS, Rosso N, Quadrifoglio F, Cesaratto L, Codarin E, Bedogni G, Beltrami CA, Tell G, et al: Subcellular localization of APE1/Ref-1 in human hepatocellular carcinoma: Possible prognostic significance. Mol Med 13: 89-96, 2007.

14. Kakolyris S, Kaklamanis L, Engels K, Fox SB, Taylor M, Hickson ID, Gatter KC and Harris AL: Human AP endonuclease 1 (HAP1) protein expression in breast cancer correlates with lymph node status and angiogenesis. Br J Cancer 77: 1169-1173, 1998.

15. Mahjabeen I, Ali K, Zhouxand Kayani MA: Deregulation of base excision repair gene expression and enhanced proliferation in head and neck squamous cell carcinoma. Tumour Biol 35: 5971-5983, 2014.

16. Poletto M, Di Loreto C, Marasco D, Poletto E, Puglisi F, Damante G and Tell G: Acetylation on critical lysine residues of Apurinic/apyrimidinic endonuclease 1 (APE1) in triple negative breast cancers. Biochem Biophys Res Commun 424: 34-39, 2012.

17. Qing Y, Li Q, Ren T, Xia W, Peng Y, Liu GL, Luo H, Yang YX, Dai XY, Zhou SF, et al: Upregulation of PD-L1 and APE1 is associated with tumorigenesis and poor prognosis of gastric cancer. Drug Des Devel Ther 9: 901-909, 2015.

18. Qing Y, Wang D, Lei X, Xiang DB, Li MX, Li ZP and Shan JL: The expression of APE1 and its correlation with prognostic significance after 252Cf radiotherapy in cervical cancer. Sichuan Da Xue Xue Bao Yi Xue Ban 40: 125-128, 2009 (In Chinese).

19. Sheng Q, Zhang Y, Wang R, Zhang J, Chen B, Wang J, Zhang W and Xin X: Prognostic significance of APE1 cytoplasmic localization in human epithelial ovarian cancer. Med Oncol 29: 1265-1271, 2012.

20. Tell G, Damante G, Caldwell D and Kelley MR: The intracellular localization of APE1/Ref-1: more than a passive phenomenon? Antioxid Redox Signal 7: 367-384, 2005.

21. Chantre-Justino M, Alves G, Britto C, Cardoso A, Scherrer L, Moreira Ados S, Quirino R, Ornellas A, Leitão A, Lage C: Impact of reduced levels of APE1 transcripts on the survival of patients with urothelial carcinoma of the bladder. Oncol Rep 34: 1667-1674, 2015.
22. Jiang Y, Zhou S, Sandusky GE, Kelley MR and Fishel ML: Reduced expression of DNA repair and redox signaling protein APE1/Ref-1 impairs human pancreatic cancer cell survival, proliferation, and cell cycle progression. Cancer Invest 28: 885-895, 2010

23. Dai N, Cao XJ, Li MX, Qing Y, Liao L, Lu XF, Zhang SH, Li Z, Yang YX and Wang D: Serum APE1 autoantibodies: A novel potential tumor marker and predictor of chemotherapeutic efficacy in non-small cell lung cancer. PLoS One 8: e58001, 2013.

24. Torre LA, Bray F, Siegel RL, Ferlay J, Lortet-Tieulent J and Jemal A: Global cancer statistics, 2012. CA Cancer J Clin 65: 87-108, 2015.

25. Chen W, Zheng R, Baade PD, Zhang S, Zeng H, Bray F, Jemal A, Yu XQ and He J: Cancer statistics in China, 2015. CA Cancer J Clin 66: 115-132, 2016.

26. Siegel RL, Miller KD and Jemal A: Cancer statistics, 2016. CA Cancer J Clin 66: 7-30, 2016

27. Mok TS, Wu YL, Thongprasert S, Yang CH, Chu DT, Saijo N, Sunpaweravong P, Han B, Margono B, Ichinose Y, et al: Gefitinib or carboplatin-paclitaxel in pulmonary adenocarcinoma. N Engl J Med 361: 947-957, 2009.

28. Socinski MA, Bondarenko I, Karaseva NA, Makhson AM, Vynnychenko I, Okamoto I, Hon JK, Hirsh V, Bhar P, Zhang H, et al: Weekly nab-paclitaxel in combination with carboplatin versus solvent-based paclitaxel plus carboplatin as first-line therapy in patients with advanced non-small-cell lung cancer: Final results of a phase III trial. J Clin Oncol 30: 2055-2062, 2012.

29. Solomon BJ, Mok T, Kim DW, Wu YL, Nakagawa K, Mekhail T, Felip E, Cappuzzo F, Paolini J, Usari T, et al; PROFILE 1014 Investigators: First-line crizotinib versus chemotherapy in ALK-positive lung cancer. N Engl J Med 371: 2167-2177, 2014.

30. National Comprehensive Cancer Network (NCCN): NCCN Clinical Practice Guidelines in Oncology (NCCN Guidelines $\left.{ }^{\circledR}\right)$ : Non-Small Cell Lung Cancer. https://www. nccn.org/professionals/physician_gls/PDF/nscl.pdf.

31. Piao BK, Tang WX, Zhang ZQ, Lin HS, Duan FW and YU GQ: The observation of Feiliuping ointment treatment of advanced lung cancer-with 339 cases of clinical analysis. J Tradit Chin Med: 21-23, 1991.

32. Li PW, Zhang DZ and Hao YX: Clinical analysis of Ping-Fei decoction treatment of 109 cases of non-small cell lung cancer. J Tradit Chin Med: 87-88, 1995.

33. Yang GW, Wang XM, Han D, et al: Study on TCM comprehensive therapy in treatment of advanced Non-Small Cell Lung Cancer. Zhong Guo Zhong Yi Yao Xin Xi Za Zhi 12: 11-13, 2005 (In Chinese).

34. Han Y, Wang H, Xu W, Cao B, Han L, Jia L, Xu Y, Zhang Q, Wang X, Zhang G, et al: Chinese herbal medicine as maintenance therapy for improving the quality of life for advanced non-small cell lung cancer patients. Complement Ther Med 24: 81-89, 2016.

35. Jiang Y, Liu LS, Shen LP, Han ZF, Jian H, Liu JX, Xu L, Li HG, Tian JH and Mao ZJ: Traditional Chinese Medicine treatment as maintenance therapy in advanced non-small-cell lung cancer: A randomized controlled trial. Complement Ther Med 24: 55-62, 2016.

36. Li W, Chen C, Saud SM, Geng L, Zhang G, Liu R and Hua B: Fei-Liu-Ping ointment inhibits lung cancer growth and invasion by suppressing tumor inflammatory microenvironment. BMC Complement Altern Med 14: 153, 2014.

37. He XR, Han SY, Li XH, Zheng WX, Pang LN, Jiang ST and Li PP: Chinese medicine Bu-Fei decoction attenuates epithelialmesenchymal transition of non-small cell lung cancer via inhibition of transforming growth factor $\beta 1$ signaling pathway in vitro and in vivo. J Ethnopharmacol 204: 45-57, 2017.

38. Pang L, Han S, Jiao Y, Jiang S, He X and Li P: Bu Fei Decoction attenuates the tumor associated macrophage stimulated proliferation, migration, invasion and immunosuppression of non-small cell lung cancer, partially via IL-10 and PD-L1 regulation. Int J Oncol 51: 25-38, 2017.

39. Livak KJ and Schmittgen TD: Analysis of relative gene expression data using real-time quantitative PCR and the 2(-Delta Delta C(T)) method. Methods 25: 402-408, 2001.

40. Guide for the care and use of laboratory animals. 8th edition. The National Academies Press. Washington, USA.

41. Zhou N, Han SY, Zhou F and Li PP: Antitumor effect of Shu-Gan-Liang-Xue decoction in breast cancer is related to the inhibition of aromatase and steroid sulfatase expression. J Ethnopharmacol 154: 687-695, 2014. 
42. Zhang QJ and Xu XP: The application of Bu-Fei decoction in lung deficiency symptom. Hubei Journal of Traditional Chinese Medicine: 34, 1999.

43. Ke MY, Li XF and Li RH: Bu-Fei decoction treatment of 32 cases of advanced lung cancer. Fujian Journal of Traditional Chinese Medicine: 21, 1995

44. Cheng XD, Hou CH, Zhang XJ, Xie HY, Zhou WY, Yang L, Zhang SB and Qian RL: Effects of Huangqi (Hex) on inducing cell differentiation and cell death in K562 and HEL cells. Acta Biochim Biophys Sin (Shanghai) 36: 211-217, 2004.

45. Shen YJ: Pharmacology of Traditional Chinese Medicine. 1st edition. People's Medical Publishing House, Beijing, China, 2000.

46. Gao XM: Pharmacy. China Press of Traditional Chinese Medicine, Beijing, China, 2007.

47. Kuo YJ, Yang JS, Lu CC, Chiang SY, Lin JG and Chung JG: Ethanol extract of Hedyotis diffusa willd upregulates G0/G1 phase arrest and induces apoptosis in human leukemia cells by modulating caspase cascade signaling and altering associated genes expression was assayed by cDNA microarray. Environ Toxicol 30: 1162-1177, 2015.

48. Lee HZ, Bau DT, Kuo CL, Tsai RY, Chen YC and Chang YH: Clarification of the phenotypic characteristics and Antitumor activity of Hedyotis diffusa. Am J Chin Med 39: 201-213, 2011.
49. Shoemaker M, Hamilton B, Dairkee SH, Cohen I and Campbell MJ: In vitro anticancer activity of twelve Chinese medicinal herbs. Phytother Res 19: 649-651, 2005.

50. Gong T, Wang CF, Yuan JR, Li Y, Gu JF, Zhao BJ, Zhang L, Jia XB, Feng L and Liu SL: Inhibition of Tumor Growth and immunomodulatory effects of flavonoids and scutebarbatines of Scutellaria barbata D. Don in Lewis-bearing C57BL/6 mice. Evid Based Complement Alternat Med 2015: 630760, 2015.

51. Shiau AL, Shen YT, Hsieh JL, Wu CL and Lee CH: Scutellaria barbata inhibits angiogenesis through downregulation of HIF-1 $\alpha$ in lung tumor. Environ Toxicol 29: 363-370, 2014.

52. Yin X, Zhou J, Jie C, Xing D and Zhang Y: Anticancer activity and mechanism of Scutellaria barbata extract on human lung cancer cell line A549. Life Sci 75: 2233-2244, 2004.

(i) $\Theta$ This work is licensed under a Creative Common Attribution-NonCommercial-NoDerivatives 4.0 International (CC BY-NC-ND 4.0) License. 